\title{
Note
}

\section{The Tower of Babel: Bridging the Divide Between Critical Race Theory and "Mainstream" Civil Rights Scholarship}

\author{
Eleanor Marie Brown
}

Poor Black people tell stories. I hear their stories daily. I have heard them in the words of a cousin who came dangerously close to losing a daughter to gang warfare. I have heard them in the words of an inmate as he explained just how a Black man from the projects had ended up on death row. I have heard them in the words of a client at the Yale clinic: the poor Black woman who explained how she made ends meet with three children and an AFDC ${ }^{1}$ check of less than $\$ 500$ a month.

Disenfranchised Black people also write poetry. I have heard poems in the words of the aspiring rap artists who frequent my hairdresser's parlor. I have heard poetry in the Negro spirituals that my grandmother sings as she braids my hair.

More privileged Black people tell stories and write poetry too. I have heard stories in the words of an uncle who was unable to buy a home in the suburbs, despite his college education and financial resources.

I too used to tell stories. Now they tell me that I write theory.

\section{INTRODUCTION}

Critical race theory challenges the exclusion of voices "from the bottom"2 in mainstream legal scholarship. Critical race theorists insist "on recognition of the experiential knowledge of people of color and our communities of origin

1. Aid to Families with Dependent Children, 42 U.S.C. $\$ \S 601-687$ (1988).

2. See Mari J. Matsuda, Looking to the Bottom: Critical Legal Studies and Reparations, 22 HARV. C.R.-C.L. L. REV. 323, 324-26 (1987). 
in analyzing law and society." As Mari Matsuda describes this project: "From the ... namelessness of the slave, from the broken treaties of the indigenous Americans, the desire to know history from the bottom has forced . . . scholars to sources often ignored: journals, poems, oral histories, and stories from their own experiences of life ...."."

Critical race theorists' use of narrative epitomizes this attempt to include voices "from the bottom." This reliance on narrative is explicitly pragmatic. First, critical race theorists use narrative in a self-conscious effort to include the voices of people of color who have traditionally been excluded from conventionally "appropriate" legal scholarship. Second, the use of narrative challenges the traditional meritocratic paradigm of the academy by attempting to subvert what are viewed as pretenses of "objectivity," "neutrality," "meritocracy," and "color-blindness." To the extent that one writes in the conventional mode, one glorifies these traditional meritocratic standards that were conceptualized in a "raced" world. ${ }^{6}$

The critical race theory "manifesto" might be characterized as follows: We, as people of color, were not there when conventional legal standards were being formulated. Little wonder that these traditional meritocratic standards have worked to exclude us historically, and still work to exclude us. Disenfranchised people of color theorize, but they theorize in different ways. They tell stories. Hear us, and hear us in our own voices. It is only then that you will truly hear us.

The response of the larger academy to this "upstart" movement has been one of decided ambivalence. It bears little resemblance to the reaction of the mainstream academy to the "outsider" movements of previous generations. A case in point is the emergence of the critical legal studies movement (CLS) two decades ago. ${ }^{7}$ When CLS first issued its most damning critiques, the academy responded vigorously. ${ }^{8}$ Liberal civil rights scholars, who saw

3. Charles R. Lawrence III et al., Introduction to MARI J. MATSUDA ET AL., WoRDS THAT WouND: CRITICAL RACE THEORY, ASSAULTIVE SPEECH AND THE FIRST AMENDMENT 1, 6 (1993) [hereinafter WORDS THAT WOUND].

4. Mari J. Matsuda, Public Response to Racist Speech: Considering the Victim's Story, in WORDS THAT WOUND, supra note 3 , at $17,19$.

5. Some examples of critical race theorists writing in the storytelling mode are: DERRICK BELL, AND We ARE Not SAVED: THE Elusive Quest fOR RACIAL JustiCE (1987) [hereinafter SAVED]; DERRICK BELL, FACES AT THE BOTTOM OF THE WELL: THE PERMANENCE OF RACISM (1992) [hereinafter FACES]; RICHARD DELGADO, RODRIGO'S Chronicles (forthcoming 1995); PATRICIA J. WilliaMS, THE AlCHEMY OF RACE AND RIGHTS (1991); Richard Delgado, Rodrigo's Chronicle, 101 YALE L.J. 1357 (1992).

6. See Charles R. Lawrence III, If He Hollers Let Him Go: Regulating Racist Speech on Campus, in WORDS THAT WOUND, supra note 3 , at 53,61 .

7. For a comprehensive explanation of the tenets of CLS, see CRITICAL LEGAL STUDIES (Allan C. Hutchinson ed., 1989); MARK KELMAN, A GUIDE to CrITICAL LEGAL STUdIES (1987); Duncan Kennedy \& Karl Klare, A Bibliography of Critical Legal Studies, 94 Yale L.J. 461 (1984); John Schlegel, Notes Toward An Intimate, Opinionated, and Affectionate History of the Conference on Critical Legal Studies, 36 STAN. L. REV. 391 (1984); Mark Tushnet, Critical Legal Studies: A Political History, 100 YALE L.J. 1515 (1991).

8. See, e.g., Paul Brest, The Fundamental Rights Controversy: The Essential Contradictions of Normative Constitutional Scholarship, 90 YALE L.J. 1063 (1981); Owen M. Fiss, The Death of the Law?, 
themselves as actively involved in challenging legal inequality, began intellectual soul-searching as they struggled to defend their project. Although the gulf between CLS and the mainstream academy has arguably never been bridged, there can be little doubt that mainstream scholars have engaged in a sustained grappling with CLS's critiques. The academy has been pushed to look within. ${ }^{9}$

When it comes to legal scholarship addressing race, by contrast, it is striking that despite the existence of critical race theory for nearly a decade, the response to it has generally been a conversation among those who identify themselves as critical race theorists. ${ }^{10}$ There simply has not been the sustained self-examination by traditional civil rights scholars that should result from the powerful critiques that critical race theory has posed to fundamental tenets of the academy. The inadequacy of the mainstream reaction to critical race theory is not reflected in the quantity of the responses. There have been persistent critics of critical race theory and of the narrative project in particular. ${ }^{11}$ Rather it is the quality of the responses that has been disappointing. Those who

72 CORNELl L. REV. 1 (1986); see also Ken Emerson, When Legal Titans Clash, N.Y. TimES, Apr. 22, $1990, \S 6$ (Magazine), at 26 (discussing level of controversy that movements like CLS have generated in legal academy).

9. A similar self-examination has resulted from the critiques that feminists of color have posed to feminist legal theory. Feminists of color have long accused feminist legal theory of essentializing, of presupposing the essence of womanhood, in their theorizing. Such theorizing minimizes the experiences of women of color who face not only the inherent gender biases of the legal system but its racial biases as well. For critiques posed by feminists of color, see, e.g, ELIZABETH V. SPELMAN, INESSENTIAL WOMAN: PROBLEMS OF EXCLUSION IN FEMINIST THOUGHT (1988); Kimberle Crenshaw, Demarginalizing the Intersection of Race and Sex: A Black Feminist Critique of Antidiscrimination Doctrine, Feminist Theory and Antiracist Politics, 1989 U. CHI. LEGAL F. 139; Angela P. Harris, Race and Essentialism in Feminist Legal Theory, 42 STAN. L. REv. 581 (1990). For the response of feminist legal scholars to these critiques, see, e.g., Patricia A. Cain, Feminist Jurisprudence: Grounding the Theories, 4 BERKELEY WOMEN's L.J. 191, 204-05 (1989-90) (arguing that "[g]ood feminist theory ought to reflect the real differences in women's realities, in our lived experiences"); Catherine A. MacKinnon, From Practice to Theory or What Is a White Woman Anyway?, 4 YALE J.L. \& FEMINISM 13 (1991) (arguing that women's subordination by men is fundamental and is not undercut by women's diversity).

10. See Charles Rothfeld, Minority Critic Stirs Debate on Minority Writing, N.Y. TIMES, Jan. 5, 1990, at B6; Jon Weiner, Law Profs Fight the Power, NATION, Sept. 4, 1989, at 246. But see Milner S. Ball, The Legal Academy and Minority Scholars, 103 HARV. L. REV. 1855 (1990) (describing himself as "outsider" and defending critical race theory, arguing that criticisms by "outsiders" are narrow, premature, and deprive the broader culture of altemative visions and narratives). The comments of Randall Kennedy in Rothfeld's article are telling: "I spent 70 pages in the Harvard Law Review taking seriously people who in my view had not been taken seriously enough. I can't think of more of a tribute to their scholarship."' Rothfeld, supra, at B6.

11. For critiques of critical race theory in general and storytelling in particular, see, e.g., Kathryn Abrams, Hearing the Call of Stories, 79 CAL. L. REv. 971 (1991); Arthur D. Austin, Deconstructing Voice Scholarship, 30 Hous. L. REV. 1671 (1993); Arthur D. Austin, Storytelling Deconstructed by Double Session, 46 U. MIAMI L. REV. 1155 (1992); Jane B. Baron, The Many Promises of Storytelling in Law, 23 RuTGERS L.J. 79 (1991); Mary I. Coombs, Outsider Scholarship: The Law Review Stories, 63 U. Colo. L. REv. 683 (1992); Daniel A. Farber \& Suzanna J. Sherry, Telling Stories Out of School, 45 STAN. L. REV. 807 (1993) [hereinafter Farber \& Sherry, Telling]; Daniel A. Farber \& Suzanna J. Sherry, The 200,000 Cards of Dimitri Yurasov: Further Reflections on Scholarship and Truth, 46 STAN. L. REV. 647 (1994) [hereinafter Farber \& Sherry, Cards]; Randall L. Kennedy, Racial Critiques of Legal Academia, 102 HARV. L. REv. 1745 (1989); Gary Peller, The Discourse of Constitutional Degradation, 81 GEO. L.J. 313 (1992); Edward L. Rubin, On Beyond Truth: A Theory for Evaluating Legal Scholarship, 80 CAL. L. REV. 889 (1992); Mark Tushnet, The Degradation of Constitutional Discourse, 81 GEO. L.J. 251 (1992). 
have taken the time to respond have largely attacked form rather than substance. As scholars have tinkered with these more peripheral questions, sadly the more fundamental questions have hardly been posed, much less answered.

Thus, when "insiders" offer critiques of this "outsider"12 scholarship, there is little fruitful dialogue. The "outsiders" and the "insiders" seem to talk past each other rather than to each other, passing by each other but never quite meeting face-to-face. ${ }^{13}$ The resulting breakdown in communication is an academic "Tower of Babel," a replication on a small scale of the biblical story ${ }^{14}$ Each group of scholars does not quite understand the other's language.

Critical race theorists simply have not been communicating with their peers. The irony of this conversation (or lack thereof) is indeed striking. Critical race scholarship has self-consciously identified itself as "outsider" jurisprudence, with the stated goal of transforming the racial exclusivity of the law, society, and the academy. Yet one cannot transform without communication. To the extent that the stated goal is transformative, critical race theory has a responsibility to communicate with the larger academy, particularly with "mainstream" civil rights liberals, who also view themselves as involved in a broader project of eliminating discrimination.

I do not argue that critical race theorists are not heard because they use narrative. It is true that narrative is an "outsider" mode of discourse in legal scholarship that has only recently begun to receive recognition. It is also true that Derrick Bell broke new ground when he wrote his Harvard Law Review Foreword in the narrative form. ${ }^{15}$ Scholars such as Robert Cover and James

12. Critical race theorists have used the term "outsider" to characterize their scholarship. See, e.g., Lawrence et al., supra note 3, at 2; Mari J. Matsuda, Affirmative Action and Legal Knowledge: Planting Seeds in Plowed-Up Ground, 11 HARV. WOMEN's L.J. 1, 1 n.2 (1988). I use the phrases "insider" and "outsider" very broadly at this point. Admittedly, it may seem unusual to group Tushnet and Kennedy, individuals with such widely varying perspectives, together. Tushnet, for example, has long been recognized as a member of the CLS movement, which itself was once viewed as an "outsider" movement. See Schlegel, supra note 7; Tushnet, supra note 7. Thus, to categorize Tushnet as representative of an "insider" philosophy is problematic. I have only utilized these phrases here to distinguish between the critical race theorists and their critics. I will distinguish the positions of the "insiders" at a later point.

13. The few exceptions in which we have seen genuine engagement of critical race theory are occasional interjections from feminist voices, since critical race theorists and feminist legal theorists might be seen as intellectual allies and at times their scholarship overlaps. See, e.g., Crenshaw, supra note 9; Harris, supra note 9 . In addition, the colloquia on law and narrative convened by prominent law reviews may be viewed as an oblique response, since narrative is a prominent mode of writing in critical race theory. See, e.g., Symposium, Legal Storytelling, 87 MrCH. L. REv. 2073 (1989).

14. Genesis 11:1-9. I borrow a biblical metaphor that Toni Morrison used so eloquently in her Nobel acceptance speech. See TONI MORRISON, LECTURE AND SPEECH OF ACCEPTANCE, UPON THE AWARD OF THE NOBEL PRIZE FOR LITERATURE, DELIVERED IN STOCKHOLM ON THE SEVENTH DAY OF DECEMBER, NINETEEN HUNDRED AND NINETY-THREE (1994).

15. Derrick Bell, The Supreme Court, 1984 Term-Foreword: The Civil Rights Chronicles, 99 HARV. L. REV. 4 (1985). Robert Cover's Harvard Law Review Foreword on narrative was not written in narrative form. See Robert M. Cover, The Supreme Court, 1982 Term-Foreword: Nomos and Narrative, 97 HARV. L. REV. 4 (1983). 
Boyd White, however, have long championed narrative as a mode of legal writing. ${ }^{16}$ Similarly, feminist scholars have been vigorous proponents of including women's stories in legal analysis. ${ }^{17}$ Critical race theory stands on ground that had been broken long before its official arrival.

I would argue that the central issue is not the use of storytelling, but the way White characters are portrayed in these stories. Critical race narratives simply have not incorporated the extensive social science research indicating an increased sophistication of White attitudes toward race. Survey research over the last two decades has consistently shown that White Americans generally do not perceive themselves as actively contributing to racial privilege. They are not the old-fashioned racists of the past-the George Wallaces and Bull Connors-"dominative" racists, ${ }^{18}$ as the social science literature terms them. ${ }^{19}$ Despite this change, the Whites in critical race stories epitomize "dominative" racists. Partly for this reason, the legal academy in general and mainstream civil rights scholars in particular do not recognize themselves in critical race narratives and thus remain unconvinced by them. ${ }^{20}$

This Note is an appeal to the critical race theory movement to draw on the wealth of empirical research about racial attitudes. ${ }^{21}$ Critical race theory presumes that "racism has contributed to all contemporary manifestations of group advantage and disadvantage along racial lines."22 This is a difficult conceptual leap, but it is not inherently more difficult than that required by the

16. See JAMES BOYD WHTtE, HERACLES' BOW: ESSAYS ON THE RHETORIC AND POETICS OF THE LAW (1985); JAMES BOYD WHITE, THE LEGAL IMAGINATION (1973); JAMES BOYD WHITE, WHEN WORDS LOSE TheIr MEANING (1984); Cover, supra note 15; Robert M. Cover, Violence and the Word, 95 YALE L.J. 1601 (1986). In addition, symposia on law and literature had been convened. Symposium, Law and Literature, 60 TEX. L. REV. 373 (1982); Symposium: Law and Literature, 39 MERCER L. REV. 739 (1988).

17. See, e.g., Catherine A. MacKinnon, Feminism Unmodified (1987); Martha Minow, Making ALL THE DIFFERENCE: INCLUSION, EXCLUSION, AND AMERICAN LAW 212 (1990); Martha Fineman, Challenging Law, Establishing Differences: The Future of Feminist Legal Scholarship, 42 FLA. L. REV. 25 (1990); Toni M. Massaro, Empathy, Legal Storytelling, and the Rule of Law: New Words, Old Wounds?, 87 MiCH. L. REV. 2099, 2105 (1989); Martha Minow, Words and the Door to the Land of Change, 43 VAND. L. REV. 1665, 1687 (1990); Robin West, Jurisprudence as Narrative: An Aesthetic Analysis of Modern Legal Theory, 60 N.Y.U. L. REv. 145 (1985).

18. JOEL KOVEL, WHITE RACISM: A PSYCHOHITORY 54 (1970).

19. These studies and this Note do not claim that this sociological dynamic makes racism or racists less pernicious. Rather, the absence of self-identified racists may indeed be much more of a threat to subordinated racial minorities.

20. This Note does not attempt to argue that unconscious racism exists. That is clearly demonstrated by social science experiments. See infra Part II. It has also been widely discussed in the critical race literature. See, e.g., Richard Delgado, Critical Legal Studies and the Realities of Race-Does the Fundamental Contradiction Have a Corollary?, 23 HARV. C.R.-C.L. L. REv. 407 (1988) (arguing Whites rarely notice acts of subtle racism, while people of color often see them; concluding that this feature influences way that people of color live their daily lives and affects legal theorizing); Charles R. Lawrence III, The Id, the Ego, and Equal Protection: Reckoning with Unconscious Racism, 39 STAN. L. REV. 317 (1987) (arguing unconscious racism has been ignored by Supreme Court).

21. I do not mean to privilege science as a mode of analysis. I believe firmly that science, like the humanities, cannot escape the influence of larger cultural and political trends. For the most comprehensive analysis of the interrelatedness of science and larger cultural forces, see THOMAS S. KUHN, THE STRUCTURE OF SCIENTIFIC REVOLUTIONS (2d ed. 1970).

22. Lawrence et al., supra note 3 , at 6 . 
"outsider" movements of other eras, be it the legal realist or the CLS movements. ${ }^{23}$ Empiricism might help "insiders" transcend the divide.

In Part I, I present a brief overview of the fundamental premises of critical race theory. I also address the common critiques of critical race theory. Part II discusses racial opinion surveys over the past four decades and a number of social science models. It shows that Whites, particularly those who identify themselves as "liberal," perceive themselves to be strongly egalitarian even though there is a wide disparity between their theoretical support of de jure equality and their actual treatment of Blacks. I offer a theoretical framework that I term "schizophrenia"24 to conceptualize modern White attitudes toward Blacks. In Part II, I employ the "schizophrenia" framework to offer a critique of critical race narratives, focusing particularly on the work of Derrick Bell, Richard Delgado, and Patricia Williams, and using my own narrative. In Part IV, I challenge critical race theory to move beyond a perfunctory recognition of the nuanced nature of White attitudes to a full incorporation of this reality into its narrative critique of legal institutions.

As an aspiring critical race theorist, I agree that "masks and other disguises" 25 must be exposed for what they are-pretenses for perpetuating subordination. We must be careful, however, that even as we struggle to have our stories included, we do not frustrate our own goals through the stories we tell. Perhaps then we will begin to speak to our peers, and only then will they truly begin to reply.

\section{CRtTical Race Theory's Challenge: AN Overview}

Critical race theorists entered the academy with a splash. Their scholarship is loud, strident, and uncompromising, not unlike the tenor that one expects of "outsider" protests. They have criticized what is termed the "dominant discourse - the collection of ideas, concepts, presuppositions, and arguments that make up liberal legalism."26 Critical race theorists charge mainstream civil rights scholars with having a "managerial view of civil rights,"27 the objective of which is the "management of tension."28 In contrast, the critical race view of civil rights is "liberation-oriented; the objective is not so much managing the status quo as changing it."29

23. See generally Schlegel, supra note 7 (discussing history of CLS); Tushnet, supra note 7 (same).

24. I do not mean in any way to demean the very real issues of mental illness. I use this metaphor mainly as an interpretive device.

25. Leslie G. Espinoza, Masks and Other Disguises: Exposing Legal Academia, 103 HARV. L. REV. 1878,1878 (1990) (exposing meritocracy and objectivity as pretexts for racism that continue to exclude people of color from academy).

26. Richard Delgado, When a Story Is Just a Story: Does Voice Really Matter?, 76 VA. L. REV. 95, 103 (1990).

27. Id. at 102.

28. Id.

29. Id. 
The traditional civil rights paradigm views racism as atypical behavior that occurs in discrete instances and can be packaged into a cognizable claim and remedied. But critical race theory holds that racism is pervasive, amorphous, and inherent in the very way that society and the judicial system are structured. In the words of a critical race theory "manifesto":

Critical race theory expresses skepticism toward dominant legal claims of neutrality, objectivity, color blindness, and meritocracy. These claims are central to an ideology of equal opportunity that presents race as an immutable characteristic devoid of social meaning and tells an ahistorical, abstracted story of racial inequality as a series of randomly occurring, intentional, and individualized acts.

... Critical race theory challenges ahistoricism and insists on a contextual/historical analysis of the law. ... [W] adopt a stance that presumes that racism has contributed to all contemporary manifestations of group advantage and disadvantage along racial lines .... Our history calls for this presumption. ${ }^{30}$

Moreover, critical race theory expresses skepticism toward the bedrock principles of the Anglo-American legal system that mainstream civil rights scholars work within:

[T] he question for us is not so much whether or how racial discrimination can be eliminated while maintaining the integrity of other interests implicated in the status quo such as federalism, privacy, traditional values, or established property interests. Instead we ask how these traditional interests and values serve as vessels of racial subordination. ${ }^{31}$

This diseased legal structure, with its claims of "neutrality, objectivity, color blindness and meritocracy,"32 cannot itself be used as presently structured to cure the disease of racism. The legal structure must first be problematized. In other words, "[t] he interests of all people of color... require not just adjustments within the established hierarchies, but a challenge to hierarchy itself.",33

Critical race theorists challenge the racialized attitudes not only of the legal system, but also of the academy. They include in their criticism even those scholars known as the "white friends" 34 of critical race theory, including the critical legal theorists and mainstream liberal scholars who also produce scholarship challenging racial hierarchy. To the extent that these

\footnotetext{
30. Lawrence et al., supra note 3, at 6 (emphasis added).

31. Id.

32. Id.

33. Id.

34. See Delgado, supra note 20, at 407.
} 
scholars have not included voices "from the bottom," their work too has been problematized. Indeed Richard Delgado created quite a stir by terming the paradigmatic liberal civil rights scholar "the imperial scholar."35

The response to critical race theory has been as controversial as the writings and techniques of its proponents. At one end of the spectrum are sympathetic critics, who reject the "voice" claims of the critical race scholars in their most extreme form, but find more dilute versions credible. Kathryn Abrams's work epitomizes this gently critical approach. ${ }^{36}$ She accepts the premise that voices "from the bottom" continue to be wrongfully excluded from legal scholarship and that this exclusion has contributed to elevating White male narratives to the status of truth. She also recognizes the real potential of narratives to expose the majoritarian biases of our legal culture. She expresses concern, however, that some proponents of the narrative project abandon legal analysis, assuming that the biases that their stories expose will be self-evident. " $\Pi] \mathrm{t}$ seems reasonable," she suggests, "to ask of narrators who are, in fact, legal scholars that their stories be framed in such a way as to shed light on legal questions." ${ }^{37}$ Other scholars, such as Mary Coombs and Edward Rubin, also fall into this "sympathetic" school. Even as they acknowledge the analytical power of the narrative project, they find critical race theory's rejection of a meritocratic system impractical, given that the academic enterprise is inherently premised on evaluative measures. ${ }^{38}$

These sympathetic critiques share a preoccupation with the problems that the narrative project-as a novel form of legal scholarship-poses for the academy, which they see as a primarily meritocratic institution. They have yet truly to grapple with the more fundamental question that the narrative project poses: challenging the legitimacy of the meritocratic paradigm in the first place. Critical race theorists are not interested in fitting into a previously established meritocratic mold. Rather, they are interested in problematizing it. The preoccupation of these critics (however sympathetic they may be) indicates that the fundamental point of the critical race critique has simply not been communicated.

On the other end of the spectrum are traditionalists who are deeply suspicious of any claim to privileged authorship based on racial heritage and are even more disturbed by suggestions that "voice of color" scholarship is "different" and should not be subject to the traditional meritocratic tenets of the academy. Randall Kennedy's decidedly unsympathetic critique of critical

35. Richard Delgado, The Imperial Scholar: Reflections on a Review of Civil Rights Literature, 132 U. PA. L. REV. 561 (1984) [hereinafter Delgado, Imperial Scholar]; see also Richard Delgado, The Imperial Scholar Revisited: How to Marginalize Outsider Writing, Ten Years Later, 140 U. PA. L. REV. 1349 (1992). The scholars criticized include Bruce Ackerman, Boris Bittker, Paul Brest, John Hart Ely, Owen Fiss, Gerald Gunther, Morton Horowitz, Kenneth Karst, and Laurence Tribe.

36. See Abrams, supra note 11.

37. Id. at 1030 .

38. See Coombs, supra note 11 ; Rubin, supra note 11 , at 929 . 
race theory represents this more traditional school. ${ }^{39}$ His has been the most controversial response to "voice" scholarship, perhaps because the author's own status as a person of color has been seen by some as a clear refutation of any claim to privileged authorship based on racial heritage. ${ }^{40}$ Unlike sympathetic critics, Kennedy is less concerned with questions of evaluation and form than with the legitimacy of critical race theory's basic premises. ${ }^{41} \mathrm{He}$ generally disputes what he calls "racial exclusion and the racial distinctiveness theses," 42 which hold that "the intellectual contributions of scholars of color are wrongfully ignored" 43 and that these scholars bring a distinct and invaluable perspective to civil rights scholarship.

Kennedy specifically disputes the existence of a "voice of color," citing Black conservatives as obvious exceptions for whom critical race theorists have failed to account. ${ }^{44}$ Furthermore, he maintains that the "voice of color" is not a worthy consideration in evaluating legal scholarship. Meritocracy, independent of the distinctive racial experience of the scholar, remains the most equitable manner for determining who gains entrance to the academy. ${ }^{45}$

39. See Kennedy, supra note 11. Kennedy's piece was controversial enough for the Harvard Law Review to convene a colloquy in response to it. See Colloquy, Responses to Randall Kennedy's Racial Critiques of Legal Academia, 103 HaRv. L. REv. 1844 (1990), including in particular, Milner S. Ball, The Legal Academy and Minority Scholars, 103 HARV. L. REV. 1855 (1990). See also Richand Delgado, Mindset and Metaphor, 103 HARV. L. REV. 1872 (1990); Espinoza, supra note 25.

40. Kennedy's critique seems mild in comparison to that leveled by Richard Epstein. Epstein finds both the techniques and scholarship of critical race theorists exclusionary. He writes:

The final conclusion is . . . a sobering one. The modern academic discourses of critical theory and new voices have thus far contributed nothing to the debate on substantive legal issues beyond the constant, repetitive assertion of their own relevance. . . . What we have are merely assertions that theirs is a large turf that outsiders may not share. . . What is needed is delivery on the promise that persons of different backgrounds can develop distinct methodologies in order to make contributions that enrich our common legal culture. How long will we have to wait?

Richard A. Epstein, Legal Education and the Politics of Exclusion, 45 STAN. L. REv. 1607, 1626 (1993). Larry Alexander has also included critical race theory in a more general critique of critical studies. Larry Alexander, What We Do, and Why We Do It, 45 STAN. L. REv. 1885 (1993).

41. The articles that Kennedy focuses on include: DeRRICK BELL, Minority Admissions as a White Debate, in RACE, RACISM AND AMERICAN LAW \$ 7.12.1 (3d ed. 1992) [hereinafter RACE]; DERRICK BELL, The Unspolen Limit on Affirmative Action: The Chronicle of the DeVine Gift, in SAVED, supra note 5, at 140; Richard Delgado, The Ethereal Scholar: Does Critical Legal Studies Have What Minorities Want?, 22 HARV. C.R.-C.L. L. REv. 301 (1987); Delgado, Imperial Scholar, supra note 35; Matsuda, supra note 12.

42. Kennedy, supra note 11 , at 1747.

43. Id. at 1745 .

44. See id. at 1778-87. Kennedy here makes a central point. This critique is what has been called "essentializing"- the tendency to argue, for example, that there is necessarily something "essential" about being Black and that all Blacks therefore subscribe to a particular point of view. Critical race theorists deny that they essentialize. In their eyes, even Kennedy writes in the "voice of color," because he is a person of color whose perceptions of the world have been fundamentally affected by race. See Alex M. Johnson, Jr., The New Voice of Color, 100 YALE L.J. 2007, 2009 (1991).

45. Stephen Carter levies a similar critique. See Stephen L. Carter, Academic Tenure and "White Male" Standards: Some Lessons from the Patent Law, 100 YALE L.J. 2065, 2066 (1991) ("I am troubled by the increasing number of academics who seem very serious about the idea that knowledge of the author's race helps create a better context for understanding the author's argument, not just on subjects relating to race, but on other subjects as well ....."); Stephen L. Carter, The Best Black and Other Tales, RECONSTRUCTION, Winter 1990, at 6. 
Daniel Farber and Suzanna Sherry offer the most thorough analysis of "voice" narratives, falling somewhere on the spectrum between the perspectives of Abrams and Kennedy. They are the "scholars in the middle-those who... believe in being open-minded but not empty headed." ${ }^{36}$ Although Farber and Sherry reject the "voice of color" thesis in its most extreme form, they accept more attenuated forms. They distinguish different strands of the "voice" thesis, ranging from the strongest version, which insists that people of color have privileged understandings of particular circumstances and texts, to weaker versions, which simply hold that people of color have distinct perspectives that continue to be excluded in legal scholarship. Farber and Sherry reject the thesis in its strongest form because it would "make the scholarship of ... whites and people of color, almost unintelligible to one another." ${ }^{\text {"47 }}$ However, they accept "a weaker version - that ... people of color can sometimes provide a perspective that is not as easily accessible to white men." 48 In their words, "The new voice is not an entirely new hue, but simply a different shade."49

Farber and Sherry are particularly concerned with the evaluative dimension. Although they recognize the delicate nature of the critical race mission, particularly with respect to "first-person agony" narratives, ${ }^{50}$ they insist on delineating objective criteria to determine the value of a story, independent of the author's cry of authenticity. They are particularly concerned that some of the stories are atypical and even untrue. ${ }^{51}$ Although stories may be intriguing, if they are atypical, they lose relevance as legal scholarship. Typicality provides a rough parallel to the empiricism demanded in other scholarly areas. Ultimately, the criteria Farber and Sherry delineate are not unlike those applied to the rest of the academy:

[W]e see no reason to retreat from conventional standards of truthfulness and typicality in assessing stories. Nor do we see any

46. Farber \& Sherry, Telling, supra note 11, at 854-55. For responses to Farber and Sherry, see, e.g, Jane B. Baron, Resistance to Stories, 67 S. CAL. L. REV. 255 (1994); Richard Delgado, On Telling Stories in School: A Reply to Farber and Sherry, 46 VAND. L. REV. 665 (1993); William N. Eskridge, Jr., Gaylegal Narratives, 46 STAN. L. REV. 607 (1994). For Farber and Sherry's responses, particularly to Eskridge, see Farber \& Sherry, Cards, supra note 11.

47. Farber \& Sherry, Telling, supra note 11 , at 819.

48. Id.

49. Id.

50. See id. at 835 . These narratives utilize an experience of racial discrimination, usually from the personal experience of the author, to illuminate some larger legal theory.

51. Mark Tushnet issues a parallel critique. He contends that the recent surge in storytelling has highlighted larger problems of integrity and judgment in legal scholarship. Although he acknowledges that narratives have real potential to fulfill one of the fundamental goals of legal scholarship, illuminating the connections between individual cases and larger legal rules, he believes that this potential has been thwarted by fundamental mistakes in literary style by storytellers. These mistakes include the heavy hand of authorial authority, self-righteousness, moral superiority, and the casual dismissal of legitimate interpretations that are too quickly seen to be racist. See Tushnet, supra note 11 . Gary Peller, a highly sympathetic critic of CLS, comes to the defense of critical race narrative in his reply. See Peller, supra note 11. 
reason to abandon the expectation that legal scholarship contain reason and analysis .... A legal story without analysis is much like a judicial opinion with "Findings of Fact" but no "Conclusions of Law. $^{52}$

Farber and Sherry, like the more sympathetic critics, seem particularly concerned with peripheral questions such as form and evaluation. They, unlike their peers, however, ultimately tie these more peripheral concerns to critical race theory's larger substantive goals. Their most damning critique suggests that critical race theorists, who identify themselves as activist scholars with a transformative agenda, may ultimately subvert their own goals through their narratives:

Effective communication requires bridging the gap between the viewpoints of speaker and listener, rather than simply presenting the speaker's views without regard to the standpoint of the listener. But in our extensive reading of the storytelling literature, we have found few efforts to connect the events in the stories with the experiences of white ... readers. Thus, whatever potential storytelling might have to change attitudes is unlikely to be realized by the current generation of efforts. ${ }^{53}$

Despite their preoccupation with form, Farber and Sherry's critiques are ultimately illuminating as they suggest a communicative chasm between the critical race theorists and their peers. I agree that this lack of communication is due in part to the dissonance between the portrayal of Whites in critical race stories and the experiences of their White readers. The White peers of critical race theorists will only respond if they are forced to see themselves in the narratives. This Note is an effort to rise to this challenge.

\section{SOCIOLOGICAL THEORY ON CONTEMPORARY WHITE ATTITUDES}

Social scientists have identified a number of salient features that characterize contemporary White attitudes toward Blacks. First, traditional stereotypes and blatant discrimination are no longer common. ${ }^{54}$ Most Whites, regardless of their political orientation, reject these traditional forms of discrimination. ${ }^{55}$ This is particularly true of White liberals who condition their behavior toward Blacks on beliefs that strongly condemn traditional discrimination. Second, Whites use ostensibly nonracial factors to justify any behavior that may have a disproportionate impact on Blacks or could be

52. Farber \& Sherry, Telling, supra note 11, at 854.

53. Id. at $826-27$.

54. See Thomas F. Pettigrew \& Joanne Martin, Shaping the Organizational Context for Black American Inclusion, 43 J. SOC. ISSUES 41, 43 (1987).

55. Howard Schuman et Al., Racial AtTtiudes in America 193 (1985). 
perceived as being racist. ${ }^{56}$ Third, Whites harbor attitudes of decided ambivalence toward Blacks resulting in extreme positive or negative reactions. ${ }^{57}$ These attitudes are amplified by individualistic notions of opportunity that cause Whites to explain disproportionate Black disadvantage by individual Black shortcomings rather than larger societal failures.

\section{A. White Attitudes Toward "Abstract" Notions of Equality}

Attitudinal surveys by social scientists almost unanimously show marked improvements in White perceptions of African-Americans and other minorities, and the commitment of Whites to using the law to prohibit racial discrimination. The most recent report of the National Research Council $(\mathrm{NRC})^{58}$ concludes that there has been a steady increase in White commitment to legal enforcement of integrationist principles. ${ }^{59}$ Northern Whites are more likely to hold egalitarian views, but Southerners have also become increasingly egalitarian. ${ }^{60}$

For example, in one of the early national surveys on school integration in 1942 , only $2 \%$ of Southerners and $40 \%$ of Northerners supported integrated schools. In 1970 , the numbers had increased to $45 \%$ and $83 \%$, respectively, and in the late $1980 \mathrm{~s}$, the percentages were even higher. ${ }^{61}$ Since the late 1950 s, the number of Whites willing to vote for a Black candidate has increased from $37 \%$ to $81 \%,{ }^{62}$ while those willing to have a Black neighbor swelled from $56 \%$ to $86 \% .^{63}$

Some social scientists were so impressed by the improved racial attitudes that they described these results as a "liberal leap."

56. See id. at 176-77.

57. James R. Kleugel \& Eliot R. Smith, Whites' Beliefs About Blacks' Opportunity, 47 AM. Soc. REV. 518,529 (1982). They have since expanded their ideas into a book. JAMES R. KLEUGEL \& ELIOT R. SMITH, BELIEFS ABOUT INEQUALITY (1986).

58. NATIONAL RESEARCH COUNCIL, A COMMON DESTINY: BLACKS AND AMERICAN SOCIETY (Gerald D. Jaynes \& Robin M. Williams, Jr. eds., 1989) [hereinafter COMMON DESTINY]. This report is widely acknowledged as the most comprehensive statistical compilation of race opinion surveys. It has documented nearly five decades of surveys, starting in 1940 and ending in 1986. The next comprehensive report will be published at the end of this decade.

59. See Paul B. Sheatsley, White Attitudes Toward the Negro, 95 DAEDALus 217, 217-18 (1966); Andrew M. Greeley \& Paul B. Sheatsley, Attitudes Toward Racial Integration, SCI. AM., Dec. 1971, at 13, 13; Herbert H. Hyman \& Paul B. Sheatsley, Attitudes Toward Desegregation, SCI. AM., July 1964, at 16, 16-23; Herbert H. Hyman \& Paul B. Sheatsley, Attitudes Toward Desegregation, SCI. AM., Dec. 1956, at 35, 35-39; D. Garth Taylor et al., Attitudes Toward Racial Integration, SCl. AM., June 1978, at 42, 42-49. The data used to support these conclusions have been based primarily on information collected by the National Opinion Research Center between 1940 and 1978 and the National Advisory Committee on Civil Disorders.

60. COMMON DESTINY, supra note 58 , at 119.

61. Id. at $116-27$.

62. Id. at 122. Recent polls showing Colin Powell's remarkable popularity suggest that this figure may be even higher. See, e.g., Dan Balz \& David S. Broder, Powell Denies Catering to Conservative Crowd, WASH. POST, Oct. 19, 1995, at A14.

63. COMMON DESTINY, supra note 58, at 122.

64. Taylor et al., supra note 59 , at $42-50$. 
concluded that attitudinal progress seemed so sweeping that research should shift from matters of broad principle to more contemporary concerns such as "the practical policies which most effectively will achieve racial justice."

\section{B. The Persistent Gap Between White Support for De Jure Equality and Public Policy Tools to Prevent Discrimination}

Yet even as White commitment to de jure racial equality has increased, the NRC report shows "substantially less support for policies intended to implement principles of racial equality." The report notes that "whites are more accepting of equal treatment with regard to the public domains of life than private domains of life, and they are especially accepting of relations involving transitory forms of contact." ${ }^{967}$

For example, although White support for desegregated schools increased by $22 \%$ between 1964 and 1978, support for federal interventionist policies to implement these principles decreased by $17 \% .^{68}$ Similar disparities between theoretical support for integration and actual implementation policies exist with respect to integration of neighborhoods, job opportunities, and access to public accommodations. ${ }^{69}$ These paradoxical trends generally remained consistent through the late $1980 \mathrm{~s}^{70}$ Moreover, Whites are more likely to support egalitarian principles if Blacks remain in the minority. Enthusiasm for sending White children to hypothetical integrated schools generally decreases as the percentage of Black children in the schools increases. ${ }^{71}$

\section{The Contradictions Between Whites' Perceptions of Themselves as Egalitarian and What They Actually Do in Their Interactions with African-Americans}

The surveys reviewed in the NRC report focus on Whites' self-perceptions. As attitudinal surveys, they decline to study Whites' actual practices and lived experiences. However, in response to some sociologists' assessment of a "liberal leap," others highlight the distinction between idealism and reality,

65. Andrew M. Greeley \& Paul B. Sheatsley, Attitudes Toward Racial Integration, in SocIAL PROBLeMS AND PUBLIC POLICY 241, 249 (Lee Rainwater ed., 1974).

66. COMMON DESTINY, supra note 58 , at 117.

67. Id.

68. Id. at 126

69. Id.

70. Id. at 127 .

71. Id. at 117,121 . There is a further point to be made. Whites express less egalitarian sentiments when they are asked what they personally would do to ensure equality as compared to what they think the law should do. When the questions move from the legal to the personal, the distinctions become especially stark. Large percentages of Whites oppose discrimination in housing, but they are decidedly less enthusiastic about living in neighborhoods that make proactive efforts to recruit Black families. Id. at 124-27. 
noting that when sociologists survey what Whites actually do as compared to what they say they will do, stark disparities emerge. ${ }^{72}$

John McConahay and his colleagues have concluded that many of the traditional tests used to survey prejudice have been influenced by White subjects' perceptions of which responses are socially desirable. ${ }^{73}$ Harold Sigall and Richard Page have found that White subjects who are under the impression that they are being psychologically monitored for truthfulness are less egalitarian in their responses than the control subjects who do not believe that they are being monitored for truthfulness. ${ }^{74}$ These sociologists agree that White Americans are not only less egalitarian than they appear, but also less egalitarian than they perceive themselves to be. They are proponents of what has been termed the "ambivalence theory" of racial attitudes. ${ }^{75}$ Such studies have led an increasing number of researchers to acknowledge the complexity of racial attitudes in the post-civil rights movement period. Gaertner and Dovidio explain that "the fundamental nature of white America's current attitudes toward blacks is complex and conflicted. ... [T] he attitudes of many whites toward blacks and other minorities are neither uniformly negative nor totally favorable, but rather are ambivalent."76

\section{Gaertner and Dovidio's "Aversive Racism" Model}

To explain this ambivalence, Gaertner and Dovidio have developed a theoretical model known as "aversive racism."77 The individuals they define as aversive racists typically claim to abhor prejudice and discrimination but sometimes exaggerate their positive behavior to confirm their nondiscriminatory perceptions of themselves. The researchers argue that when their subjects display negative feelings about African-Americans, this is done in "subtle, rationalizable ways." The "aversive racism" model holds that there is a veneer of acceptance of racial equality among many Whites (as indicated by stated belief) without internalization (as indicated by behavior). ${ }^{79}$

The aversive racism model predicts that aversive racists will be particularly cognizant of acting appropriately in interracial contexts. It further suggests that

72. See, e.g., Samuel L. Gaertner \& John F. Dovidio, The Aversive Form of Racism, in PREJUDICE, DisCrimination, AND RACISM 61 (John F. Dovidio \& Samuel L. Gaertner eds., 1986); Irwin Katz et al., Racial Ambivalence, Value Duality, and Behavior, in PREJUDICE, DISCRIMINATION, AND RACISM, supra, at $35,42-44$.

73. John B. McConahay et al., Has Racism Declined in America?: It Depends on Who Is Asking and What Is Asked, 25 J. CONFLICT RESOL. 563 (1981).

74. Harold Sigall \& Richard Page, Current Stereotypes: A Little Fading, A Little Faking, 18 J. PERS. \& SOC. PSYCHOL. 247, 250-54 (1971).

75. See Katz et al., supra note 72 , at 35.

76. Gaertner \& Dovidio, supra note 72 , at 61 .

77. Id.

78. Id. at 62 .

79. Id. at 84-86. For an earlier discussion of this terminology, see Herbert C. Kelman, Processes of Opinion Change, 25 PUB. OPINION Q. 57, 60-66 (1961). 
a subject's concern about external perceptions that she is not racist serves as a monitor on behavior toward Blacks. Given these predictions, the researchers anticipate clearer instances of discrimination when the "normative structure within the situation is weak, ambiguous, or conflicting." ${ }^{30}$ On the other hand, when the normative structure is "clear and unambiguous," will be more difficult to deny, and behavior should be more strictly nonracist. $^{82}$

Based on this theoretical framework, the researchers devised a number of protocols that presented White subjects with situations varying from "weak, ambiguous, or conflicting" norms to "clear and unambiguous" norms. ${ }^{83}$ They then studied White responses to African-Americans in these situations. ${ }^{84}$ The protocols they devised tested the willingness of liberal Whites to be outwardly helpful toward Blacks.

In one such experiment, the researchers focused on Whites who belonged to a political party that was widely perceived to be liberal. Their behavior was contrasted with Whites who belonged to a party that was perceived to be conservative (subsequently referred to in this Note as "nonliberals"). ${ }^{85}$ Wrong-number phone calls were made to the subjects' houses; these phone calls soon transformed into requests for assistance. The caller indicated that she was attempting to call a garage from the highway since her car had broken down. She had run out of coins and asked for the subject's help in contacting the garage. If the subject hung up after the explanation or declined to help, the response recorded was "not helping." A "premature hang-up" indicated that the subject disconnected prior to hearing the motorist's predicament. ${ }^{86}$

The researchers found that those who identified themselves as liberal were significantly more helpful to Blacks than nonliberals were. ${ }^{87}$ However, there was a paradox in the data. Liberals hung up prematurely on Blacks in significantly higher percentages than they did on Whites. Black male callers were particularly susceptible to this treatment by liberals. ${ }^{88}$

Some of the subjects who identified themselves as liberals and some who declined this identification were polled about what they anticipated they would do if they received such a phone call. Across the board, they insisted that they

80. Gaerner \& Dovidio, supra note 72 , at 66 .

81. Id.

82. Id.

83. Id.

84. Id. at 68 .

85. Id.

86. Id.

87. Nonliberals aided Blacks and Whites in $65 \%$ and $92 \%$ of calls, respectively. For those who identified themselves as liberals, the disparity was far less striking; they helped Blacks and Whites in $75 \%$ and $85 \%$ of calls, respectively. Id. at 69 . Gaertner and Dovidio indicate that callers were "clearly identifiable from their dialects" as being Black or White. Id. at 68.

88. Twenty-eight percent of liberal respondents prematurely ended a call from a Black man. Only $10 \%$ hung up prematurely on a White man. Id. 
would be helpful without regard to the person's race. ${ }^{89}$ The results of the experiment fit well with the predictions of the "aversive racism" paradigm. When it was clear that a person was in need, liberals helped Blacks and Whites almost equally. In these instances, the normative structure was unambiguous: According to widespread norms of social responsibility, we should help people in difficult situations. Before the motorist's needs were clear, however, when all that was known was that the caller had reached a wrong number, liberals hung up disproportionately on Blacks, and particularly Black males. ${ }^{90}$ In this situation, it was easier for a liberal's suppressed feelings toward Blacks to emerge. ${ }^{91}$

\section{E. Kleugel and Smith's Model}

The study discussed above focused on Whites' perceptions of Black people. However, as James Kleugel and Elliot Smith emphasize in their landmark study, Whites' Beliefs About Blacks' Opportunity, such studies do not address the racial issues that preoccupy the increasingly sophisticated White minds of the post-civil rights period. ${ }^{92}$ Kleugel and Smith conclude that "[i]n general, the literature on whites' racial attitudes has focused on conventional racial prejudice, to the neglect of studying beliefs about blacks' opportunity."

Kleugel and Smith identified a representative sample of the White adult population. They randomly chose their subjects from within the sample and interviewed them by telephone. The researchers posed a series of questions to assess Whites' beliefs about institutional barriers to Blacks' opportunities. Approximately $75 \%$ of the Whites surveyed believed that some type of discrimination still existed. ${ }^{94}$ Yet at the same time, $73 \%$ maintained that the

89. Id. at 69.

90. Id. In another protocol, Gaertner and Dovidio investigated the White propensity to use indirect nonracial factors to justify differential behavior toward African-American coworkers. See id. at 75.

91. Irwin Katz and his colleagues propose a different theory, "ambivalence-amplification," to account for contradictory sentiments expressed by Whites toward Blacks. See Katz et al, supra note 72. They explain that most Americans "view race as a categorical disability deserving of special aid, much like physical handicap and impoverishment in old age. Blacks should be helped because they have been down so long."' Id. at 41 (quoting S. M. Lipset \& W. Schneider, The Bakke Case: How Would It Be Decided at the Bar of Public Opinion, I PUB. OPINION 38, 41 (1978)). Yet many Whites also believe that Blacks' "lack of ambition, laziness, and failure to take advantage of opportunities" make their plight worse than it need be. Id. (quoting ANGUS CAMPBELl, WhITE ATTITUDES TOWARD BLACK PEOPLE 14 (1971)). The result is a tension within Whites between these two sentiments, which produces diametrically opposed emotions- "friendliness and sympathy on one side and disdain and aversion on the other"- -with both sides pulling for allegiance. Id. at 42 . The central prediction of the ambivalence theory is that these conflicting attitudes within the White subject will produce erratic behavior with regard to the Black person in question.

Pettigrew and Martin have argued that Blacks display similarly complex and conflicted reactions toward even well-intentioned efforts by Whites to improve Black opportunities, a phenomenon that they term "black ambivalence." See Pettigrew \& Martin, supra note 54, at 51.

92. Kleugel \& Smith, supra note 57, at 518-29.

93. Id. at 519 .

94. Id. 
opportunities available to Blacks were equal to or even greater than those available to the average American. ${ }^{95}$ Moreover, nearly a third of the Whites surveyed thought that chances for Blacks to get ahead were better than those for the average American. ${ }^{96}$ Finally, among Whites surveyed, the majority was convinced that reverse discrimination was a widespread problem (53\%). ${ }^{97}$

Kleugel and Smith's study proposes an explanation for the unidimensional character of recent changes in Whites' racial attitudes. For most Whites, the race problem reduces simply to racial tolerance and ensuring equality of rights. ${ }^{98}$ The average White American assumes that the opportunities available to her are equally available to other Americans. The prominence of egalitarian notions in mainstream discourse reinforces these views. Given this premise, it is rational to assume that another's place on the ladder of social success is directly related to that individual's willingness to take advantage of her opportunities. $^{99}$

\section{F. Providing a Larger Theoretical Framework: The Metaphor of Schizophrenia}

These theories share a finding of what I would characterize as "schizophrenia." The actions of White subjects in particular circumstances seem contradictory in light of what they believe in principle and how they perceive themselves. This implicitly discriminatory behavior occurs even as opinion surveys indicate increasing friendliness to integration and a decreasing tendency to assign negative stereotypes to African-Americans.

It is striking that social science researchers, despite the different behaviors they observe, consistently resist labeling this behavior as conventionally racist. This reluctance occurs even as they bring a heavy dose of skepticism to their White subjects' perception of themselves. These social scientists reject 'the widespread existence of genuinely pro-black, favorable components of whites' racial attitudes that are independent of egalitarian values. Sympathy without additional feelings of friendship or respect does not in their view represent a truly positive racial attitude." 100 Yet, even these skeptics reject the notion that Whites who pay lip service to racial equality while shirking substantive results are knowing participants in racial discrimination.

This is not to deny naively that old-fashioned racism-"dominative racism" in Kovel's language ${ }^{101}$ - has disappeared. Such racism, however,

95. Id.

96. Id. at 520 .

97. Id. at 519.

98. Id. at 523 .

99. Id.

100. Gaertner \& Dovidio, supra note 72 , at 62 .

101. See KoveL, supra note 18 , at 32. 
plays a minor role in White attitudes in the post-civil rights movement era. Nor do these observations suggest an unwillingness in the social science community to recognize the reality of continued racial subordination, even as researchers argue that these behaviors defy conventional categorization.

Cornel West makes a parallel argument in his account of how race is constructed in mainstream public discourse. ${ }^{102} \mathrm{He}$ too senses what I would characterize as a societal "schizophrenia," a large-scale societal analogue to what sociologists observe in individuals: equivocation between one of two extremes, fluctuating between the "Scylla of environmental determinism and the Charybdis of a blaming-the-victims perspective." ${ }^{\text {103 }}$ There is no sense of a coherent middle. One sentiment maintains that government can play a positive role in the elevation of depressed living conditions, but is unwilling to criticize behavior in the African-American community. Another sentiment focuses on the work ethic and moral behavior of poor Blacks, with little discussion of an economic framework for improvement of their conditions. One camp focuses on the structural to the exclusion of the behavioral $;^{104}$ the other focuses on the behavioral to the exclusion of the structural. Egalitarianism or individualism? Oppressed or lazy? I believe that this larger societal ambivalence can only work to exacerbate the tensions in Whites, leading to an amplification of the divergence between egalitarian instincts and self-perception, on the one hand, and actual behaviors, on the other hand.

Labeling contemporary White behavior as conventionally racist undermines our ability to confront these attitudes in their present manifestation. I believe the challenge for critical race theory is to reflect this "schizophrenia," as it exists both in the minds and attitudes of modern-day White individuals and on a societal level.

\section{UNPACKING THE NARRATIVES}

To demonstrate that critical race theory has failed as yet to meet this challenge, I next examine the work of three exponents of narrative in critical race theory: Derrick Bell, Richard Delgado, and Patricia Williams.

\section{A. Bell}

In The Unspoken Limit on Affirmative Action: The Chronicle of the DeVine Gift, ${ }^{105}$ Derrick Bell's heroine, Geneva Crenshaw, a civil rights litigator of enormous capabilities, is appointed to a tenure-track position at one of the

102. See CoRnel West, RaCE MATters (1993).

103. Id. at 57 .

104. Id. at 11-14.

105. DERRICK BELL, The Unspoken Limit on Affirmative Action: The Chronicle of the DeVine Gift, in SAVED, supra note 5, at 140. 
nation's prestigious law schools. Overburdened by the multiple demands that are placed on minority professors, ${ }^{106}$ she is visited by a mysterious man, $\mathrm{Mr}$. DeVine Taylor. Like her, Taylor is concerned about the low minority representation on the faculty and offers his help.

With his considerable funds, he launches a large-scale campaign to identify and recruit the most talented young minorities interested in teaching. Within two years, he discovers six talented teachers of color who are all hired by the law school, producing a faculty of unparalleled diversity among law schools of comparable caliber. It is when DeVine Taylor discovers the Seventh Candidate that a problem arises:

The academic credentials of this, the Seventh Candidate, were impeccable. The top student at our competitor school, he had edited the law review and written a superb student note. After clerking for a federal court of appeals judge and a U.S. Supreme Court Justice, he had joined a major New York City law firm where, after three years of work they rated "splendid," he was in line for early election to partnership. Now, though, the DeVine people had inspired him to teach. ${ }^{107}$

The faculty, however, responds negatively to the Seventh Candidate. The dean explains to Crenshaw that the school had decided to recommend the Seventh Candidate to other national law schools rather than hire him: “"This is one of the oldest and finest law schools in the country. It simply would not be the same school for our students and the alumni with a predominantly minority faculty ...."'108 He adds that "'a law school of our caliber and tradition simply cannot look like a professional basketball team."'109

Bell proceeds to analyze whether the Supreme Court would sustain a claim of racial discrimination if this candidate filed suit. He concludes that despite the Seventh Candidate's impeccable credentials, the law school would prevail based on its impressive record of hiring minorities. ${ }^{110}$ Moreover, Bell believes that the Court would be unwilling to question the intricate considerations involved in the hiring of the elite of the profession. ${ }^{111}$

In Neither Separate Schools nor Mixed Schools: The Chronicle of the Sacrificed Black Schoolchildren, ${ }^{112}$ Black schoolchildren vanish into thin air on the first day of the planned implementation of a school desegregation plan.

106. See Richard Delgado, Minority Law Professors' Lives: The Bell-Delgado Survey, 24 HARV. C.R.C.L. L. REV. 349, 369 (1989) (concluding from survey data that "[1]arge numbers of minority law professors are overworked").

107. BELL, supra note 105 , at $142-43$.

108. Id. at 143 .

109. Id. at 144 .

110. Id. at 150 .

111. Id. at 149 .

112. DERRICK BELL, Neither Separate Schools nor Mixed Schools: The Chronicle of the Sacrificed Black Schoolchildren, in SAVED, supra note 5, at 102. 
White parents privately conclude that "it was all for the best." 113 In yet another chronicle, ${ }^{114}$ the government channels all its efforts into devising a cure for rich White children stricken with a "Ghetto Disease" that causes behavior strangely reminiscent of that traditionally associated with (and confined to) poor inner-city Blacks. Blacks are quickly scapegoated for transmitting their social ills to wealthy Whites. When a cure is devised, it is federally funded. Over the protests of legislators of color, it is administered solely to White children.

Finally, in The Space Traders, ${ }^{115}$ visitors from outer space offer to erase the federal deficit, clean up the environment, and replenish depleted energy supplies. In exchange, however, they want every Black citizen to return with them to their planet. They offer no indication of what they plan to do with these Black citizens. White support for the exchange runs high. Whites attribute Black opposition to paranoia, claiming that Blacks have no basis for the fear that they will be ill-treated by the Space Traders. Furthermore, in the Secretary of the Interior's opinion, "'every red-blooded American with an ounce of patriotism""116 would be willing to serve their country in this regard.

After the President fails to convince the Space Traders to take only those Blacks under the purview of the criminal justice system, a constitutional convention is convened to pass the Twenty-Seventh Amendment. The Amendment reads as follows: "Without regard to the language or interpretations previously given any other provision of this document, every United States citizen is subject at the call of Congress to selection for special service for periods necessary to protect domestic interests and international needs." 117 Given the passage of the Amendment, the Supreme Court refuses to declare the plans unconstitutional, and Blacks are shipped off into outer space. Bell describes a situation reminiscent of the slave trade: "Heads bowed... black people left the New World as their forebears had arrived." 118

Bell's narratives may broadly be characterized as allegories, or at the very least fables. ${ }^{119} \mathrm{He}$ has chosen this literary device for a profoundly activist reason. The narratives are meant to accomplish a goal: They are an "in-yourface" wake-up call. He hopes to challenge the race-loaded actions that are so commonplace that they are no longer questioned: "common sense" or

113. Id. at 103.

114. DERRICK BELL, The Declining Importance of the Equal-Protection Clause: The Chronicle of the Amber Cloud, in SAVED, supra note 5, at 162.

115. DERRICK BELL, The Space Traders, in FACES, supra note 5, at 158.

116. Id. at 165 .

117. Id. at 185.

118. Id. at 194.

119. I acknowledge that fables conventionally use nonhuman characters. However, at times Bell's characters seem strangely nonhuman. 
background noise. His stories attempt to push us to cease justifying the unjustifiable.

I fully agree with Bell's objectives. Our society needs a wake-up call. His critiques are right on target with respect to the continued pernicious results of White racism, particularly in Black eyes. The power and accuracy of his message are undeniable: White priorities are consistently valued over Black priorities. This societal prioritization continues to undermine even wellintentioned attempts to provide legal protections and remedies.

Yet his narratives miss the mark in other ways. I grant that, as allegories, they are not meant to be taken literally. But with these pieces of fiction, Bell hopes to convey a profound and disturbing nonfictional moral. His portrayal of Whites as old-fashioned racists undermines his ability to convey his nonfictional message. I believe Bell's objective could be accomplished much more powerfully were he to juxtapose the nuanced and ambivalent nature of contemporary White racism with the perniciousness of the results. His characters would alternate between outwardly helpful behavior toward Blacks (thus reinforcing an egalitarian self-image) and disparate treatment justified with "race-neutral" reasons.

At times we see traces of this nuanced and conflicted behavior. In The Chronicle of the DeVine Gift, for example, the dean reminds Geneva Crenshaw that he had already hired six candidates of color. Moreover, he had taken special efforts to recommend the Seventh Candidate to other law schools. Yet within the same breath he proceeds to equate six minority candidates with a predominantly minority faculty. These are undoubtedly instances of behavior that support an egalitarian self-image juxtaposed with a quick return to racist reasoning.

Sadly, however, Bell's character then relapses into the world of the oldfashioned dominative racist, comparing his law school to "a professional basketball team." Bell hopes to solidify the reader's sense of moral outrage, but instead he undermines his own objectives. A more accurately portrayed dean would likely have found entirely different reasons not to hire the Seventh Candidate. More realistically, the law school might, for example, have implemented a moratorium on faculty hiring, only to reverse itself a few months later to hire a promising White candidate.

Similarly, the "Ghetto Disease" cure would never be federally funded, for in this very explicit form, it could not survive a constitutional challenge. It would simply be so expensive that only rich Whites would have access to it, in a country where Blacks (particularly Black men) are disproportionately likely to lack adequate health insurance. ${ }^{120}$ Bell's point is well taken: Were

120. See COMMON DESTINY, supra note 58, at 430 . Black people, particularly Black men, are disproportionately unlikely to have access to either acute or preventative medical services. When they do receive medical services, they are likely to be of lower quality than those received by the general population. See Isabel Wilkerson, Medical Experiment Still Haunts Blacks, N.Y. TIMES, June 3, 1991, at 
significant portions of White youth experiencing the ills of the inner city, this would be perceived as a national emergency. Again, I acknowledge that the end result is equally pernicious: Black life is undervalued and underfunded. There are simply more sophisticated means of portraying contemporary racism that accomplish the same ends.

Bell's Space Traders narrative also goes too far. There are more complex, less blatant mechanisms that society uses to marginalize Blacks short of galactic deportation. Indeed, Bell would do well to listen to his own characters. The most telling portion of The Space Traders narrative is the comment of a Black woman who recognizes that Blacks' fate would not be different on Earth, even as she acknowledges the subtlety of modern race discrimination. Bell should listen more closely to the voice he gave her:

"If the Space Traders were to depart, carrying away with them what they and everyone else says can solve our major domestic problems, wouldn't people increasingly blame us blacks for increases in debt, pollution and fuel shortages? We might have saved ourselves-but only to face here a fate as dire as any we face in space."121

Her ambivalence speaks to his larger project. Perhaps the current marginalization of poor Blacks from the national consciousness is metaphorically analogous to expulsion to outer space. But the point is that there is no need for narratives to depict the expulsion of Blacks to outer space. We need look no further than expulsion to the desperate conditions of the inner city $^{122}$ or the criminal justice system. ${ }^{123}$ Moreover, no constitutional convention would be needed to achieve this result. Other means would do the job just as effectively. Equal protection precedents would be distinguished, interpreted narrowly, and excused on procedural grounds, allowing such behavior to proceed constitutionally. ${ }^{124}$

Bell himself has asserted that when he recounts the story of the Space Traders to Black audiences, large majorities immediately consider such an

A12 (discussing meeting of medical professionals to discuss lack of poor Black access to medical facilities caused in part by lingering racism in medical establishment).

121. BELL, supra note 115, at 193. Her words are indeed prophetic: They prefigure in an eerie manner the recent national debate surrounding Proposition 187 and the California Civil Rights Initiative (surely a misnomer!).

122. See Douglas S. MASSEY \& NANCY A. DENTON, AMERICAN APARTHEID: SEgREgation AND THE MAKING OF THE UNDERCLASS 13 (1993) (Inner cities "concentrate[] conditions such as drug use, joblessness, welfare dependency, teenage childbearing, and unwed parenthood, producing a social context where these conditions are not only common but the norm.").

123. See generally COMMON DESTINY, supra note 58, al 22-23. "Blacks are arrested, convicted, and imprisoned for criminal offenses at rates much higher than are whites. Currently, blacks account for nearly one-half of all prison inmates in the United States; thus blacks' representation in prisons is about 4 times their representation in the general population." Id.

124. See generally Richard T. Ford, The Boundaries of Race: Political Geography in Legal Analysis, 107 HARV. L. REV. 1841 (1994) (discussing impact of Court interpretation of civil rights law on housing segregation in inner cities). 
occurrence to be possible. In contrast, majorities of White audiences initially maintain that it would never happen. When further challenged by Bell, however, some are willing to concede that the larger White community would be complicit in such a result. Yet they steadfastly exclude themselves from complicity. ${ }^{125}$ This assertion says something fundamental about the people with whom Bell is not communicating-precisely the people with whom he most needs to communicate. On one level, Bell lets his White readers off too easily. His narratives are not solely aesthetic. By his own terms, they are part of an activist educational enterprise. But his stories allow White readers to escape asking the essential question: Why would any legal scholar feel the need to write narratives that seem so strange and alien in the first place? It is only when readers grapple with this question that they realize that the stories must in some way represent some aspect of Bell's reality as a Black man. To provoke this reaction, Bell and other critical race theorists need to problematize the portrayal of Whites in their stories.

\section{B. Delgado}

Perhaps no critical race story demonstrates the potential and the pitfalls of the narrative project better than Richard Delgado's final Rodrigo chronicle. Cultural Power, the Law Reviews, and the Attack on Narrative Jurisprudence, ${ }^{126}$ is one of a series of conversations between a fictional professor of color (who bears a remarkable resemblance to Delgado) ${ }^{127}$ and a brilliant former student turned law professor named Rodrigo, ${ }^{128}$ of Italian and African-American extraction. In this final chronicle, the two fictional

125. Telephone Interview with Tanya Coke, Research Assistant to Professor Derrick Bell (Oct. 8, 1995). The striking dissonance between Black and White perceptions of particular incidents is demonstrated particularly well by the Tuskegee syphilis experiment. Poor Black sharecroppers in Alabama suffering from syphilis, who sought treatment from public clinics, were given the impression that they were being treated while scientists used them as human subjects so that they could observe the advanced stages of the disease. They were never treated, even after penicillin proved to be effective, but they were led to believe that they were being cured. At a symposium of health professionals convened to increase Black confidence in the medical establishment, symposium speakers tried to convince Black audience members that the Tuskegee experiment was not the result of a White conspiracy. For many, however, these efforts were to no avail. Indeed, some have applied the lessons of Tuskegee to contemporary realities and suspect that similar experiments account for the prevalence of AIDS in the Black community. A New York Times editorial deemed this reaction "bizarre," see The AIDS "Plot" Against Blacks, N.Y. TIMES, May 12, 1992, at A22, but many find it understandable in the light of historical evidence such as Tuskegee, see Jason DeParle, For Some Blacks, Social Ills Seem to Follow White Plans, N.Y. TIMES, Aug. 11, 1991, § 4, at 5 (discussing justifications for Blacks" "conspiracy theories"); Wilkerson, supra note 120 (discussing legacy of Tuskegee experiment).

126. Richard Delgado, Rodrigo's Final Chronicle: Cultural Power, the Law Reviews, and the Attack on Narrative Jurisprudence, 68 S. CAL. L. REV. 545 (1995) [hereinafter Delgado, Rodrigo's Final Chronicle].

127. He is referred to simply as "Professor" throughout the narratives. However, for the purposes of clarity, I will refer to him as Delgado, since he resembles Delgado so profoundly. Indeed, Delgado attributes to the professor many of the articles he himself has written.

128. Rodrigo is the brother of Geneva Crenshaw, a civil rights lawyer and fictional construct of Derrick Bell. See supra text accompanying notes 105-11. 
scholars come much closer to communicating with their peers than in any other critical race narrative. ${ }^{129}$ Ironically, as close as Rodrigo and Delgado come to bridging the divide, they fall just short of the realistic portrayal of their White peers needed for true communication.

Rodrigo, a recently hired professor contemplating his publication options, approaches the "fictional" Delgado to discuss the possibility of writing one of his early articles in the storytelling mode. Delgado surprises himself by advising Rodrigo against it, despite his own decision to forgo similar advice he was given early in his career. Delgado argues frankly that such a decision is sure to endanger Rodrigo's tenure prospects: "Rodrigo, as you must know, the whole movement is under attack. Some consider it mushy, unrigorous, even nonlegal. You should think carefully before writing in that vein. Unless you have exceptional colleagues, it might be best to hold off until you have tenure." 130 Rodrigo candidly expresses his deep personal doubts; clearly he has no desire to become an idealistic martyr for the movement. ${ }^{131}$ Referring to his colleagues, he notes, "[a] couple of them showed thinly disguised scorn when I spoke of using a storytelling and narrative-analysis approach." 132

Rodrigo then goes one step further to argue that different types of narrative provoke differing levels of hostility. He dubs one category of narratives the "'agony' tale or first person account."133 Rodrigo explains that these are somewhat controversial but often meet a positive response. "Everyone loves the agony tale. They find them so poignant, so moving, so authentic, so true. They accept them immediately and call them poetic and soulful." 134 Delgado enthusiastically concurs. "The reaction often reminds me of the Harlem Renaissance when white folks discovered black culture." $135 \mathrm{He}$ continues, speaking from personal experience: "Early in my career I wrote an article that in some respects was a classic agony tale. ... It was an early piece on hate

129. Former conversations between the two have ranged far and wide, from discussions on the potential of the free market to repair the problems of racism to cultural inertia as an impediment to litigation-based reform and civic republicanism. See Richard Delgado, Rodrigo's Second Chronicle, The Economics and Politics of Race, 91 MICH. L. REv. 1183 (1993) (book review); Richard Delgado, Rodrigo's Fourth Chronicle: Neutrality and Stasis in Antidiscrimination Law, 45 STAN. L. REV. 1133 (1993) (book review); Richard Delgado, Rodrigo's Fifth Chronicle: Civitas, Civil Wrongs, and the Politics of Denial, 45 STAN. L. REV. 1581 (1993). The other chronicles include Delgado, supra note 5; Richard Delgado, Rodrigo's Third Chronicle: Care Competition and the Redemptive Tragedy of Race, 81 CAL. L. REV. 387 (1993) (book review); Richard Delgado, Rodrigo's Sixth Chronicle: Intersections, Essences, and the Dilemma of Social Reform, 68 N.Y.U. L. REV. 639 (1993); Richard Delgado, Rodrigo's Seventh Chronicle: Race Democracy and the State, 41 UCLA L. REV. 721 (1994); Richard Delgado, Rodrigo's Eighth Chronicle: Black Crime, White Fears-On the Social Construction of Threat, 80 VA. L. REV. 503 (1994); Richard Delgado, Rodrigo's Ninth Chronicle: Race, Legal Instrumentalism, and the Rule of Law, $143 \mathrm{U}$. PA. L. REV. 379 (1994). The chronicles will be compiled in a forthcoming book, Rodrigo's Chronicles.

130. Delgado, Rodrigo's Final Chronicle, supra note 126, at 548.

131. Rodrigo says this quite explicitly: "I'm torn ... . I want to write the best possible article, yet I want to survive to fight again another day." Id. at 558.

132. Id. at 556 .

133. Id. at 551. Delgado here borrows a term coined by Farber and Sherry.

134. Id. at 552 .

135. Id. 
speech."'136 Many of his White peers went out of their way to congratulate him and empathize:

I would go to conferences ... a and people I never even knew would come up to me and say ... how moved they were, and how terrible it was that the law didn't redress the harm of racial insults.

....

... I finally figured out why everyone loved that ... article. It's because they could empathize with the black subjected to the vicious racial slur. They could say how terrible it is that our legal system doesn't provide redress. . . . Indeed, I think it allowed them to say to themselves how much they loved the First Amendment. They loved it so much that they had to sacrifice these unfortunate Negroes and Mexicans, for which they were genuinely sorry and apologetic. ${ }^{137}$

Thus, although "agony" narratives are still somewhat unsettling, they often produce a sympathetic response.

Another group of narratives engenders no such sympathy. It is this group, the most controversial, in which Rodrigo is primarily interested. This includes the "counterstory," which "'mocks, jars, displaces or attacks some majoritarian tale or narrative, such as without intent no discrimination exists; or the free market will drive out discriminators; or some other such tenet of the majoritarian faith."'138 Again, Delgado concurs from personal experience:

A few years later I wrote one on the campus hate-speech controversy. In this one, I didn't so much make a case for curbing hate speech as I did for the indeterminacy of the usual First Amendment analysis.... This one my liberal friends welcomed much less, although in a way it was a more sophisticated analysis. Then, recently, I published a piece showing that the marketplace of ideas is unable to redress systemic injustice-although it can correct minor social ills and errors-because the more deeply inscribed, systemic ones are simply invisible.... My ACLU buddies absolutely hated this one. ${ }^{139}$

These "counterstories" are the most controversial. ${ }^{140}$

136. Id. at 553 .

137. Id. at 553-54.

138. Id. at 552 .

139. Id. at 554 .

140. In Rodrigo's eyes, Bell's Space Traders falls into this genre, "'Consider ... the strong reaction ... Space Traders elicited. The point of the chronicle is that white self-interest drives the civil rights movement, accounting for the many zigs and zags of our racial history. It ends by showing that white America would sell out the cause of black rights today, just as it did 200 years ago, if the price were right." Delgado concurs: "When one of us takes on one or more of these comforting myths of racial progress, of course there is trouble." Id. at 552. Rodrigo seems to admire this genre the most. Unfortunately, at the end of the piece we are still unsure as to Rodrigo's decision. 
Delgado's narrative is so intriguing precisely because it confronts directly the dilemma that is at issue in this Note, a dilemma that few other critical race theorists have broached: the gaping communication gap between critical race scholars and their White peers. Delgado indicates through his choice of issue that he is not prepared to sit merrily writing narratives with little regard for the response of his colleagues. His concern is well placed, not only in light of Rodrigo's self-interest (as a young professor hoping to achieve tenure), but because he recognizes that he is engaged in an activist enterprise. ${ }^{141}$ That enterprise does not afford him the luxury of writing narratives that are not actively molding opinions. ${ }^{142}$ Indeed, he says this explicitly when speaking through the voice of Rodrigo:

[S]torytelling has the potential to change the social background against which legal decisions are interpreted. It can make inroads into the interlocking system of meanings, cultural understandings, and interpretations that determine the 'common sense' southern officials and other actors bring to legal and cultural decisions. It can make cases like Brown succeed, not fail. ${ }^{143}$

Through this recognition of the basic importance of dialogue with White peers, Delgado has made a fundamental step toward improving communication. His White peers are not irrelevant. Indeed, they are fundamental to the success of his project.

In this respect, the chronicle may be the most perceptive of the critical race narratives. Delgado has identified his audience, and the clear implication is that it includes Whites. He argues that even a decision with as powerful a moral imperative as Brown has little hope of success if it comes up against the cultural resistance of officials who minimize its impact at every turn. This is the "common sense," the background noise that needs to be challenged. Taking Delgado's argument to the next logical step, there is little hope of challenging this "common sense" without reaching White readers. Doing so does not

There is yet another category of stories that is clearly out of the question for Rodrigo. These are unlikely to provoke the degree of controversy that has met the critical race narratives. These narratives are supported and encouraged; in fact, they are often not recognized as narratives. Rodrigo explains these "majoritarian" tales:

White folks tell stories, too. But they don't seem like stories at all, just the truth. So when one of them telis a story, ... few ... ask whether it is authentic, typical or true. No one asks whether it is adequately tied to legal doctrine, because it and others like it are the very bases by which we evaluate legal doctrine. White tales like these seem unimpeachable.... Id. at 553 .

141. Id. at 558.

142. There is clearly a separate question as to whether the predominantly White ivory tower of the academy is the most effective place to fight battles for racial justice. That is another question for another day. This Note is premised on the notion that battles for racial justice may be fought in a variety of arenas, including the academy. Given that these scholars have chosen to struggle within the academy, the question is in some sense moot. The aim should be to maximize effectiveness in whatever venue one chooses.

143. Delgado, Rodrigo's Final Chronicle, supra note 126, at 563. 
require validating their perspectives. On the contrary, it should involve the opposite-challenging White perspectives. However, to challenge these perspectives effectively, we must meet them on their own terms.

Of the allegorical narrative writers, Delgado comes closest to achieving this. He has his finger on the pulse of the ambivalent feelings that social scientists describe in their White subjects. The "fictional" professor speaks of his initial confusion at the alternating reactions of encouragement and hostility that he would find in his peers. His experience is a direct correlate of the "schizophrenia" described in the previous part.

White society has ample mechanisms to deal with "agony" tales; indeed, these tales provide an opportunity for reinforcement of the egalitarian selfimage. Agony tales focus on single instances of bigoted behavior, which White society can minimize as the behavior of deviants who have transgressed the ideals of the larger community. She may be ostracized by the community, thus reinforcing the notion that "she is not like us." The wholesale condemnation of these incidents by Delgado's colleagues provides an opportunity for "symbolic cleansing."144 Whites' egalitarian self-perceptions are left intact and may even be reinforced. Little wonder that Delgado receives encouragement as long as he writes these stories.

The counterstories pose a much more intractable problem. It is not surprising that they elicit the more hostile or defensive side of Whites' ambivalent attitudes. These stories criticize the very core of institutions that his White colleagues take for granted-indeed, they indict the entire legal structure for its racial biases. It is not a huge jump to see that his colleagues themselves are implicated.

Delgado's greatest contribution is his resistance to portraying his colleagues in the mold of old-fashioned dominative racists. He repeatedly refers to them as his "liberal friends" and his "ACLU buddies."145 For this reason, he is much less susceptible to accusations of attacking relics of the past.

Yet he still falls short of portraying his colleagues' racial attitudes in their sophisticated contemporary manifestation. It is one thing to recognize that his colleagues are ambivalent and conflicted. It is quite another thing to incorporate fully this recognition into narrative theorizing, to follow its full implications through to the end. Given this recognition, one may not so easily dismiss colleagues as First Amendment and meritocracy groupies. For a belief in these tenets is part and parcel of the "ambivalence" described by the social science literature. On the one hand, there are the egalitarian sentiments imparted by the civil rights movement; on the other hand, there is a

144. This is a phrase used by Professor Reva Siegel. Feminist and Critical Race Theory Workshop, Yale Law School (Feb. 24, 1995).

145. Delgado, Rodrigo's Final Chronicle, supra note 126, at 554, 566. 
socialization that consistently emphasizes the primacy of the individual. It is this socialization that accounts at least in part for the elevated status accorded to concepts such as free speech and meritocracy.

Thus, one may not so easily dismiss these concepts as pretexts for racial discrimination, for they are key elements of the egalitarian self-image. On the contrary, they must be confronted head-on and recognized as legitimate beliefs. This would allow Delgado a much more powerful context in which to reflect on the ways in which these concepts are inherently "raced," even as they are valid concerns that must be confronted. Given the historical context in which they were developed, these concepts should not be used as "neutral" tools to analyze narratives. However, narratives must confront them directly to make this point to White peers.

Delgado has already taken two fundamental steps. His narratives recognize the fundamental importance of communicating with his White peers and incorporate a recognition that contemporary Whites are ambivalent and conflicted. Unfortunately, his later misstep limits the progress achieved in these first two steps. Delgado stops just short of portraying his colleagues where they are now. Should he incorporate the full implications of this recognition into his narrative theorizing, his colleagues could hardly ask for more. It will then be up to them to reply.

\section{Williams and a Critique: My Own Narrative}

Patricia Williams's techniques are different. Her project is less allegorical in nature than either Bell's or Delgado's. She largely forgoes fiction to write from personal experience. This technique poses different challenges in the effort to meet White readers and bridge the communicative chasm.

In The Alchemy of Race and Rights, Williams writes:

I was shopping in Soho and saw in a store window a sweater that I wanted to buy for my mother. I pressed my round brown face to the window and my finger to the buzzer, seeking admittance. A narroweyed, white teenager wearing running shoes and feasting on bubble gum glared out, evaluating me for signs that would pit me against the limits of his social understanding. After about five seconds, he mouthed "We're closed," and blew pink rubber at me. It was two Saturdays before Christmas, at one o'clock in the afternoon; there were several white people in the store who appeared to be shopping for things for their mothers.

I was enraged. ...

...

... On the day after that, I found I was still brooding, so I turned to a form of catharsis I have always found healing. I typed up as much of the story as I have just told, made a big poster of it . . . and 
after Benetton's was truly closed, stuck it to their big sweater-filled window. I exercised my first-amendment right to place my business with them right out in the street. ${ }^{146}$

A few months later, Williams wrote an article for a law review that had convened a colloquium on "excluded voices." Using her "Benetton" story, she analyzed "how the rhetoric of increased privatization ... functions as the rationalizing agent of public unaccountability and ultimately, irresponsibility." ${ }^{\text {"147 }}$ She writes:

Weeks later, I received the first edit. . . . [M]y fury had been carefully cut out. My rushing, run-on-rage had been reduced to simple declarative sentences. ...

... All reference to Benetton's had been deleted.... [T]he editors told me that they were not in the habit of publishing things that were unverifiable. I could not but wonder, in this refusal even to let me file an affidavit, what it would take to make my experience verifiable. The testimony of an independent white bystander? (a requirement in fact imposed in U.S. Supreme Court holdings through the first part of the century)....

... All reference to my race had been eliminated because it was against "editorial policy" to permit descriptions of physiognomy. . . . In a telephone conversation to them, I ranted wildly about the significance of such an omission. "It's irrelevant," ... "It's nice and poetic," but it doesn't "advance the discussion of any principle . . . . This is a law review, after all." Frustrated, I accused him of censorship ... . "This is just a matter of style," he said with firmness and finality. ${ }^{148}$

There are two stories missing from this narrative, which sociological studies indicate are essential to a fuller understanding: the narrative of the Benetton clerk and the narrative of the law review editor who decided that it was a matter of "editorial policy" to omit all references to her race. Williams cannot ask (much less answer) the really difficult questions because she has not included the narratives of the White participants. Indeed, it is only then that the narrative becomes that much more analytically useful for understanding exactly what the store clerk was thinking as he excluded Williams, a Columbia Law School professor, middle-class in attire, from the store. ${ }^{149}$ The narrative would then achieve its truer potential to get us beyond our current understanding of how to combat such behavior.

146. PATRICIA J. Williams, The Death of the Profane: A Commentary on the Genre of Legal Writing, in THE ALCHEMY OF RACE AND RIGHTS, supra note 5 , at $44,44-46$.

147. Id. at 47.

148. Id. at $47-48$ (citing Blyew v. United States, 80 U.S. 581 (1871), upholding a state's right to forbid Blacks to testify against Whites). Williams notes, "my story became one of extreme paranoia without the information that I am black." Id. at 47.

149. This is, at least, my personal impression of her. 
A stream of questions is left unanswered by the narrative. How would the store clerk justify his attempt to exclude her given her relatively obvious social and educational status? Does Black skin obliterate any of the usual class signals which (sadly) we use to distinguish people in this society? Can Williams ever educate herself out of racist treatment at his hands? Does he have ostensibly "race-neutral" reasons? What are they? Would he, in a fit of guilt, recognizing his wrongdoing, admit every other Black person who approaches the store for the day? What about the irony of Williams's exclusion from a chain that refers in its multiracial advertisements to "The United Colors of Benetton"? What is the significance of this advertisement to the store clerk? Does he work there because he is more comfortable in a company with a "liberal" image? What was his reaction to the poster that Williams posted in the window the next day? Did her behavior seem "irrational"? Did he have any idea that the poster was referring to him?

And what about the law review editor? Would an affidavit from an independent White bystander really help? Why did Williams not ask him? How is it that he could find her race "irrelevant" and "poetic," even as the law review itself had convened a colloquium on "excluded voices"? Was this not another attempt to exclude, to impose his interpretation on Williams's "Blackness"? Why did his law review accept Williams's article in the first place? How did the editor's encounter with Williams affect his further dealings with Benetton?

I have no doubt that Williams's interpretation of the story is correct. Yet I also have no doubt that both the store clerk and the law review editor would dispute aspects of her interpretation. For me the really difficult (and I maintain much more interesting) question is to consider how and why the same experience resonates so differently with different people. I argue that we stand to learn much more about the way in which this society is "raced" if we ask the White literary subjects questions, just as sociologists do.

My interest in the White narratives is not an interest in corroboration by an "independent white bystander." Williams's narrative, standing on its own, resonates strongly with me. Last spring, I (along with another Black customer) was nearly thrown out of a prominent store frequented by Yale students in New Haven. ${ }^{150}$ An "assistant manager" argued "that he had enough of our types." Which "types" could he mean, I thought with a touch of irony? Being a regular customer, I had long noticed his tendency to keep Black customers waiting as he served White customers who were behind us in line. Exhausted after a long night of studying and tired of educating store clerks who were reluctant to serve Black customers, I chose not to confront him that morning. I recalled my mother's oft-repeated advice that I need to choose my battles.

150. The name of the store was included in an earlier draft of this Note, on file with the Yale Law Journal. 
That morning, however, another Black customer chose this battle and confronted the assistant manager. When the employee denied any racial animus (even as he had insisted he had had enough of "our types"), my patience ran out, and I interceded to aid the Black customer. The assistant manager immediately said that we were "threatening," and picked up the phone to call the New Haven police. "This is private property. I am about to throw you out," he said. (I, too, am frustrated by the "language of privatization" that Williams critiques.)

I, like Williams, am absolutely convinced that this confrontation was only about my race. But I also agree with Williams that "[s]ubject position is everything in ... analysis of law." "I51 I sat at my computer that evening to relieve the continuous frustration of "Blackness" that had been exacerbated yet again by my experience. I hoped my work would mitigate the depressed mood that inevitably followed such incidents. "Not today, sweet Jesus," I prayed silently, and I consoled myself by recalling the deep joys that also come with Black skin. Yet I realized that as an activist (as compared to an aesthetic) enterprise, I could not write my narrative without the narrative of the Whites with whom I interacted. I wondered how they perceived me to be threatening in my J. Crew clothing and penny loafers, with a laptop computer by my side. Moreover, I remembered deliberately subduing the anger rising within and my (perhaps futile) attempt to speak quietly. I did not perceive myself to be shouting (even as I had every reason to be shouting!). What was the clerk's impression of the Black man who parked a luxury car in front of the store and was accompanied by a White woman sporting a mink coat and an expensive engagement ring? ${ }^{152}$

I have been surprised in later conversations with the White individuals with whom I interacted in the store. Their perceptions were totally different from mine. They thought I was shouting, and they did not notice my J. Crew clothing, penny loafers, or laptop computer. The reactions of the police officers were remarkably similar. They too did not notice the sweatshirt I was wearing that advertised my graduation from an Ivy League school. Not surprisingly, they also did not notice the Black man's luxury car nor his companion's mink

151. See PatRicia J. Williams, The Brass Ring and the Deep Blue Sea: Some Parables About Learning To Think Like A Lawyer, in THE ALCHEMY OF RACE AND RIGHTS, supra note 5, at 1, 1.

152. In reflecting on the incident, I recall the very public apology that Earl Graves, Jr., the son of the prominent Black entrepreneur, Earl Graves, elicited from the New York Port Authority for police harassment. My response to the special attention he received as the son of a prominent Black businessman was decidedly ambivalent. Should I rejoice for the public apology and the accompanying New York Times editorial berating the Port Authority police? Is this just another instance of "symbolic cleansing" to appease guilty White consciences? Or could it be that the police might think twice the next time they stop a Black man? Is such use of class privilege a justifiable tactic to negotiate the high psychological price that comes with a Black skin? Or does one quietly moum for the thousands of other Black survivors of lesser socioeconomic status who have no similar recourse? See The 6:42 From Chappaqua, N.Y. TMES, May 11, 1995, at A28. For a response to this editorial expressing similarly ambivalent sentiments, see Douglas Thea, Black Men Daily Face Suspicion and Prejudice, N.Y. TIMEs, May 16, 1995, at A20 (letter). 
coat. They did, however, notice that she was White. They steadfastly denied that they were affected by the apparent interracial relationship. One White participant specifically noted my thick West Indian accent and subsequently pointed out that I was not like "them," apparently believing my charges of racism to be ridiculous. I jumped on this opportunity to communicate my point. What did he mean by "them?" "Nothing," he insisted, quickly changing the topic. Retrospective revisionism? Could it be that I had indeed benefitted from my West Indian heritage? I was reminded with yet another pang of guilt how Blacks of identifiable West Indian extraction often experience benefits not available to American-born Blacks.

What is possibly unsurprising to others (but profoundly surprising to me) is that the moment they heard I was hoping to become a civil rights lawyer, their perception of me changed. The manager of the store called, apologized for his associate's behavior and begged me not to sue. Perhaps the recent lawsuit against Denny's had made an impression on him. ${ }^{153}$ I surprised myself. As an aspiring critical race theorist, I am inherently suspicious of the mainstream civil rights project and "rights" rhetoric. Yet somehow, "rights" rhetoric had struck the fear of God into this manager. I was frightened as I found myself taking solace in these "rights" of which critical race theorists have been so critical. ${ }^{154}$ They serve a psychologically comforting purpose. The store manager was undoubtedly reifying the "rights" rhetoric. Was I doing this too?

Williams's initial story and perhaps my own, if given without the accounts of the White employees, strike chords with many Black people. But to a White audience, such stories risk being less compelling. The real story is much more complicated than Williams's literary terrain suggests. We must include White characters in their truly "schizophrenic" forms if critical race narratives are to breach communicative divides, reach wider (and Whiter) audiences, and change minds-the goal of any activist project.

153. The NAACP filed a multimillion-dollar lawsuit against Denny's for a systematic pattern of refusing to serve Black customers in restaurants across the country. The Justice Department intervened for the plaintiffs. Denny's ultimately settled the case for an undisclosed amount, with promises to subject itself to continued surveillance to ensure that their practices had changed. It also promised to provide more opportunities for Black franchise operators. See Howard Kohn, Service with a Sneer, N.Y. TIMES, Nov. 6, 1994, \& 6 (magazine), at 43.

154. For critical race theorists' discussion of the advantages and disadvantages of rights rhetoric, see Kimberle W. Crenshaw, Race, Reform, and Retrenchment: Transformation and Legitimation in Antidiscrimination Law, 101 HARV. L. REV. 1331 (1988); Patricia J. Williams, Alchemical Notes, Reconstructing Ideals from Deconstructed Rights, 22 HARV. C.R-C.L. L. REV. 401 (1987). 


\section{CONCLUSION: THE RACELESS EPOCH? ${ }^{155}$}

Kendall Thomas coined the phrase "we are raced" 156 as a raceconscious challenge to the abstract notions of citizen and state as they are conceptualized in liberal legalism. Thomas claims that our received notions of rights and duties in law are rife with racial implications. This is particularly the case given the highly charged racial context within which notions of rights and duties were developed, who they were meant to exclude, and our societal struggle to make the law "color-blind." 157 In this context, abstract notions of citizen, government, rights, and duties do not begin to account for the relationship between people of color and their government, people of color and their fellow White citizens, and people of color among themselves, either as traced out in history or in contemporary times. Critical race theorists insist that the world is not as de-raced as the law, historically formed by members of the majority race, would have it seem.

I agree with the critical race theorists. We must learn to resist the sentiment that we can somehow rid ourselves of this "race thing." Such theorizing does damage to our perceptions of social relations, as it attempts to bracket off race in formulating theories of how notions of citizen, law, and the state are constructed. We retard the educational project by failing to come to terms with the enormity of race and how it subsumes us. We standardize race without recognizing that we do it, and this inhibits our efforts to fight racial subjugation. Social science tells us this is the case. "Race becomes 'common sense'-a way of comprehending, explaining and acting in the world."158 Thomas is right. We are indeed "raced."

Where I disagree with the critical race theorists is over the intricacies with which the theory is worked out. Critical race theory needs a formulation of race that takes account of White people's realities. It seems to me that the very fact that we confront a "raceless" paradigm, where people are unaware of how race affects their everyday lives, forces us to incorporate this "racelessness" into any critical race theorizing. To some extent this has been done; a fundamental goal of critical race theory has been to expose the ostensibly raceneutral "masks and other disguises"159 that perpetuate racial oppression. The problem is that in attempting to strip away masks, we have written as though

155. This is a play on the title of one of Bell's many narratives. See Derrick Bell, After We're Gone: Prudent Speculations on America in a Post-Racial Epoch, 34 ST. LovIS U. L.J. 393 (1990).

156. See Lawrence, supra note 6, at 61 (quoting Kendall Thomas, Comments at Frontiers of Legal Thought Conference, Duke Law School (Jan. 26, 1990)); see also Telephone Interview with Kendall Thomas, Professor of Law, Columbia University (Apr. 14, 1994).

157. The notion is often attributed to Harlan's famous dissent in Plessy, in which he stated: "Our constitution is color-blind." Plessy v. Ferguson, 163 U.S. 537, 559 (1896) (Harlan, J., dissenting).

158. MiCHaEl OMI \& Howard WinANT, RACIAL FORMATION IN THE UNITED STATES: FROM THE 1960s TO THE 1990s, at 60 (1994).

159. Espinoza, supra note 25 , at 1878. 
contemporary Whites operate no differently than the dominative racists of the past. We can acknowledge that Whites may indeed believe that their agendas are race-neutral and not merely a pretext for maintaining subordination. To my mind the point of the phrase unconscious racism is that it is unconscious. ${ }^{160}$

Critical race theory does often acknowledge the unconsciousness of White actions; an important goal of the movement is to expose to the law how this unconsciousness leads to acute and nasty realities in the lives of people of color. Yet, I believe that critical race theory has yet to ask itself the much more difficult question - that is, how to communicate with people who really believe that tools that maintain racial subordination are race-neutral, people who were raised in paradigms of meritocracy and objectivity and who steadfastly maintain that the law is color-blind.

Critical race theory has achieved a profound insight without recognizing its full implications. We need to move beyond a simple recognition of the way in which we have been socialized to think we are "raceless," to incorporate the implications of that realization into the way that the critical race movement theorizes. Too often, critical race theorists write of unconscious racism while forgetting in the same breath that it is indeed unconscious.

Any formula that would move beyond the present impasse would have to account for this reality. I think such a formulation would recognize that even as we are indeed raced, we are necessarily raced to varying extents. Whether or not we realize we are raced necessarily implicates the extent to which we are raced. As people of color, we have no choice but to be raced. Others have the choice to operate in a paradigm of racelessness, for their racial features constitute society's norms. The White subjects of the social science experiments I described differ from the critical race theorists in their fundamentally different sense of the importance of race in this world.

Some of us are raced, others of us are de-raced, and there is a continuum in between. The ambivalent Whites who struggle with conflicting allegiances of how to conceptualize Blacks seem to be arrayed at various points along this continuum. In the formulation that I propose, critical race theorists should approach each instance of an individual's contact with the law and include the voices of White participants. Then we should theorize about how that individual's perceptions vary depending on race. We should write narratives that incorporate different people's realities.

Indeed, as starkly foreign as critical race theory's premises seem to traditional civil rights scholars, the movement is fundamentally a plea to be let in. Critical race theorists have not abandoned the law. ${ }^{161}$ That is simply not

160. See Lawrence, supra note 20.

161. Ostensibly, then, the "outsiders" and the "insiders" are to some extent working (albeit in different ways) toward similar goals. Little wonder that Scott Brewer issued a plea for common cause, noting that "Kennedy and his critics do share a goal whose importance is so overwhelming as to dwarf instrumental 
a luxury that they can afford. As Matsuda writes, "Ours is a law bound culture. If law is where racism is, then law is where we must confront it."162

Critical race theory in that respect is very much within the law and within the legal academy. It is a plea to legal scholarship to consider some distinct perspectives. Let us in, perhaps on our own terms, but nevertheless let us in. The paucity of communication undermines the very object of critical race theory, which is to bring distinctly different voices into legal analysis. Critical race theory must be careful to apply its own critique of the dominant paradigm to itself. Critical race theorists too write from a position of subjectivity, as we are on a mission to expose what we consider a pretense of objectivity. White attitudes are central to our enterprise not only because of what we as people of color perceive them to be, but also because of what Whites perceive their own attitudes to be. As we argue that our realities have been left out of their stories, do we not then have some responsibility to make sure their realities are not left out of ours?

In the absence of this incorporation of the perspectives of White participants in critical race narratives, it will seem as though we are attacking yesterday's shadows. Our colleagues do not see themselves in the critical race narratives, just as we do not see ourselves in much of their scholarship. Unless there is progress, we can be sure that mainstream civil rights scholars will continue to operate within the paradigm of race neutrality, while those who recognize the significance of race will continue to talk past them.

The biblical metaphor beckons us forward. Scholarly interaction requires us to move beyond the Tower of Babel. We must strive to forge communicative understanding, a shared discourse in which marginalized voices are not only aired but heard.

disagreement about the best ways to achieve it." Scott Brewer, Introduction: Choosing Sides in the Racial Critiques Debate, 103 HaRv. L. REV. 1844, 1854 (1990).

162. See Matsuda, supra note 4 , at 51. 


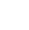

